УДК 340.134

DOI https://doi.org/10.17308/vsu.proc.law.2021.3/3557

\title{
МЕЖДУНАРОДНОЕ ПРАВОВОЕ РЕГУЛИРОВАНИЕ ВОЗМЕЗДНОГО ПРИЖИЗНЕННОГО ДОНОРСТВА ОРГАНОВ ДЛЯ ТРАНСПЛАНТАЦИИ: ПРОБЛЕМЫ ПРИМЕНЕИЯ
}

\author{
А. В. Басова \\ Саратовский государственный медицинский университет \\ илени В. И Разуловского \\ Поступила в редакцию 17 мая 2021 г.
}

\begin{abstract}
Аннотация: проводится анализ развития международного правового регулирования возмездного донорства органов для трансплантации с иелью выявления возможности его применения и широкого развития. Автор приходит к выводу о недопустилости развития правовой практики возмездного донорства в странах, так как это приводит к нарушению распределения органов для трансплантаиии, их незаконному обороту, дискрилинации социально незащищенньх групп населения.

Ключевые слова: возлездное донорство, органы, трансплантация, леждународное регулирование, дискриминация, права человека.
\end{abstract}

\begin{abstract}
: the article analyzes the development of international legal regulation of paid organ donation for transplantation in order to identify the possibility of its application and wide development. The author comes to the conclusion that it is unacceptable to develop legal practices of paid donation in countries, as this leads to a violation of the distribution of organs for transplantation, their illegal trafficking, and discrimination against socially vulnerable groups.

Key words: paid donation, organs, transplantation, international regulation, discrimination, human rights.
\end{abstract}

Международное правовое регулирование является международным стандартом и правовым ориентиром для национального законодательства стран по соблюдению прав и свобод человека, в том числе в области донорства органов и трансплантации. Международные правовые акты призваны гармонизировать национальные законодательства, а следовательно, и правоприменительную практику в той ссрере правоотношений, которую они регулируют. В настоящее время в различных странах мира наблюдается рост числа трансплантаций почки от живого донора, не связанного с реципиентом генетическим или иным родством. В 2017 г. в США было проведено 1124 неродственных пересадок почек от живого донора реципиенту; в Мексике - 358; в Сирии - 129 ; в Нидерландах - 113; в Израиле - 109; в Саудовской Аравии - 105; в Великобритании - 92; в Бразилии - 80; в Австралии - 49; в Кувейте $-26^{1}$. Представленная ста-

${ }^{1}$ См.: Михель Д. В., Резник О. Н. Перспективы развития прижизненного неродственного донорства в России : междисциплинарный анализ // Апории совре-

(C) Басова А. B., 2021 
тистика неродственного прижизненного донорства почек указывает на актуальность исследования международного правового регулирования возмездного донорства органов.

Первые международные правовые акты в области трансплантологии запрещают возможность применения возмездного донорства. Декларация о трансплантации человеческих органов от 1987 г. $^{2}$ говорит о том, что купля-продажа человеческих органов строго осуждается мировым сообществом и не содержит положений о возможности применения прижизненного донорства органов для трансплантации. Руководящие принципы ВОЗ по трансплантации органов от 1991 г., принятые резолюцией WHA44.25, устанавливали возможность безвозмездного пожертвования органов живыми донорами реципиентам, находящимся в генетическом родстве друг с другом ${ }^{3}$, что следует оценить положительно, поскольку генетическое родство обеспечивает баланс этических и правовых интересов живого донора и реципиента, исключает корыстную заинтересованность сторон и незаконный оборот органов.

Конвенция о правах человека и биомедицине от 1997 г. ${ }^{4}$ устанавливает, что тело человека и его части не должны быть источником получения финансовой выгоды, но не уточняет для кого - донора, реципиента или для третьих лиц.

Этот пробел был восполнен Стамбульской декларацией о трансплантационном туризме и торговле органами (Стамбульская декларация). Изъятие органа у живого донора, с предоставлением ему дополнительных узаконенных мер социальной и финансовой поддержки не является торговлей органами, поскольку под ней данный международный правовой акт подразумевает наём, вербовку, транспортировку, перемещение живых и умерших людей или их органов, а также укрывательство, подделку документов, с применением угроз, силы, служебного положения или других форм принуждения, похищения, мошенничества и обмана; передачу, получение третьей стороной оплаты или других выгод для приобретения контроля над потенциальным донором - в целях получения от него органов для трансплантации ${ }^{5}$.

менной трансплантологии / под ред. О. Н. Резника. M., 2020. URL: https://ssrn. 274 com/abstract=3488672 (дата обращения: 10.05.2021).

2 Декларация о трансплантации человеческих органов. Мадрид (Испания). 1987 г.URL: https://uapravo.com/hro/text.php?lan=ukr\&id=9289\&id_book=9289\&id_ parent $=9289 \& i d \_v i d \_r e s=(11 \mathrm{https}: / /$ uapravo.com/hro/text.php?lan=ukr\&id =9289\&id_book=9289\&id_parent=9289\&id_vid_res=11 (дата обращения: 10.05.2021).

${ }^{3}$ Руководящие принципы ВО3 по трансплантации органов от 1991 г. URL: https://apps.who.int/iris/bitstream/handle/10665/202917/WHA44_11_rus.pdf? sequence=1\&isAllowed=y (дата обращения: 10.05.2021).

${ }^{4}$ Конвенция о правах человека и биомедицине от 1997 г. URL: https://base. garant.ru/2562155/ (дата обращения: 10.05.2021).

${ }^{5}$ Стамбульская декларация о трансплантационном туризме и торговле органами от 2008 г. URL: http://transpl.ru/files/npa/ stambul_skaya_deklaraciya.pdf (дата обращения: 10.05.2021). 
Стамбульская декларация признает за государствами право самостоятельного решения целесообразности прижизненного неродственного донорства для трансплантации и рекомендует учитывать в национальных законодательствах не только медицинский критерий отбора доноров и их добровольного согласия, но и психосоциальный, направленный на исключение психоэмоциональных нарушений донора, что не исключает его социально-экономическую заинтересованность.

Выплаты за акт состоявшегося донорства рекомендуется рассматривать не как оплату за орган, а как компенсацию за лечение реципиента, возложенную на органы, ответственные за его лечение (правительственные органы здравоохранения, страховые компании). К выплатам донору органов могут относиться: компенсация за понесенные убытки и его утраченный доход, стоимость организационных затрат (на транспорт, размещение, продовольственное обеспечение, международные телефонные переговоры), медицинские затраты, связанные с лечением донора после выписки. Странам, где нет универсального медицинского страхования рекомендуется обеспечить страхование жизни, здоровья, инвалидизации донора, а странам, где система медицинского страхования развита, - доступ к медицинской помощи доноров. Прижизненное донорство органов не должно быть препятствием в трудоустройстве, страховании жизни и здоровья человека.

Следовательно, Стамбульская декларация узаконила возмездное изъятие органов у донора, если оно предусмотрено национальным законодательством, и компенсация ущерба производится государством. Вышеперечисленные меры социальной поддержки живого донора за лечение реципиента скорее необходимы для малоимущих граждан, поскольку материально обеспеченный человек вряд ли будет жертвовать своим органом, нанося умышленно вред своему здоровью, и ожидать компенсацию от государства, в которой он социально и материально не заинтересован. Участники Стамбульского саммита, проведенного в Стамбуле Трансплантационном обществом (TTS) и Международным обществом нефрологии (ISN) в 2008 г., при принятии Стамбульской декларации, безусловно, понимали проблему неравного положения малоимущего населения планеты в системе возмездного донорства, но подписали ее, пренебрегли их интересами сохранения здоровья, возможно, с целью развития своей профессиональной деятельности.

В 2010 г. Всемирная организация здравоохранения принимает новые Руководящие принципы ВОЗ по трансплантации человеческих клеток, тканей и органов ${ }^{6}$, в пятом принципе которых установлено, что запрет на продажу или покупку клеток, тканей или органов не исключает возмещения разумных и поддающихся контролю расходов, понесенных донором, включая потерю дохода или оплату издержек, связанных с уходом,

6 Руководящие принципы ВОЗ по трансплантации человеческих клеток, тканей и органов от 2010 г. URL: https://www.who.int/transplantation/Guiding PrinciplesTransplantation_WHA63.22ru.pdf (дата обращения: 10.05.2021). 
обработкой, сохранением и передачей человеческих клеток, тканей или органов для трансплантации.

Создание финансовых стимулов международными правовыми актами способствует, на наш взгляд, дискриминации социально уязвимого, бедного населения планеты, даже если они производятся государством. Исторические и современные факты свидетельствуют об этом. Например, в Средневековье бедняки (ремесленники и крестьяне) за гроши продавали свои здоровые зубы дантистам, которые использовались в ортодонтических конструкциях для богатых знатных особ․ ${ }^{7}$ В Индии прижизненное неродственное донорство почек для трансплантации осуществляет бедное население, для которого денежная компенсация на некоторое время облегчает их материальное положение ${ }^{8}$. В современном демократическом обществе недопустимо использовать одних людей в качестве объектов удовлетворения потребностей других, в том числе при восстановлении состояния здоровья.

Статья 4 Конвенции Совета Европы против торговли человеческими органами ${ }^{9}$, незаконными изъятиями органов и тканей у живого донора признает забор органов с нарушением норм внутреннего законодательства. Пункт 2 ст. 4 данной Конвенции имеет отсылочную норму на параграф 2 этой статьи, где указывается на возможность закреплять в национальном законодательстве исключительные случаи изъятия органов у живого донора без его согласия.

Президент РФ В. В. Путин в своем распоряжении Министерству иностранных дел указал о необходимости выражения мнения от имени Российской Федерации при подписании Конвенции Совета Европы против торговли человеческими органами, что наша страна решительно осуждает (невзирая на возражения многих государств) положения Конвенции о возможности стран сделать в своем законодательстве оговорки, допускающие изъятие человеческих органов без согласия живого донора. Данное положение является отступлением от высоких стандартов Совета Европы в области прав человека, существенно подрывающее устанавливаемый Конвенцией режим борьбы с бесчеловечными преступлениями ${ }^{10}$.

Трудно не согласиться с данным авторитетным мнением. Изъятие органов при жизни человека без его согласия является не только преступлением, но и наивысшим проявлением насильственных действий государства над своими гражданами, даже если они будут материально

${ }^{7}$ См.: Биопротезирование. История и современность / А. М. Морозов [и др.] // Современные проблемы науки и образования. 2019. № 4. С. 139.

${ }^{8}$ Cм.: Sachdeva S. Organ donation in India: Scarcity in abundance // Indian J Public Health. 2017. Vol. 61, № 4. P. 299-301.

9 Конвенция Совета Европы против торговли человеческими органами ETS № 216 (Сантьяго-де-Компостела, 25.03.2015). URL: https://base.garant. ru/71221344/1b93c1 34b90c6071b4dc3f495464b753/ (дата обращения: 10.05.2021).

${ }^{10} \mathrm{O}$ подписании Конвенции Совета Европы против торговли человеческими органами : распоряжение Президента РФ от 24 июня 2015 г. № 195-рп // Собр. законодательства Рос. Федерации. 2015. № 26. Ст. 3887. 
компенсированы государством. Данный вид донорства не признан официально ни в одном государстве.

В настоящее время Иран является единственной страной, имеющей легальную систему оплаты донорства органов, которая была введена еще в 1988 г. и показала свою эфффективность, так как за год программы была ликвидирована очередь на трансплантацию почки. Пациент, нуждающийся в трансплантации и не имеющий подходящего родственника, желающего пожертвовать орган, а также при отсутствии подходящего органа от посмертного донора для трансплантации может обратиться в некоммерческую ассоциацию пациентов с диализом и трансплантацией (Datpa), в которой ведется реестр потенциальных доноров. Возможность участия человека в прижизненном донорстве определяют врачи на основе исследования его здоровья. В случае участия граждан в программе прижизненного донорства Правительство Ирана выплачивает донорам компенсацию в размере 1200 долларов и медицинскую страховку на один год. Даритель получает также вознаграждение от реципиента или от благотворительных организаций. Однако исследователи данной модели возмездного донорства отмечают некоторые ее недостатки: ненадлежащее последующее лечение доноров, бедность и неграмотность доноров почек, в то время как большинство реципиентов образованы и богаты ${ }^{11}$.

В Новой Зеландии в 2016 г. был принят закон «Compensation for Live Organ Donors», который ввел государственные меры поддержки живых доноров, пожертвовавших почку или часть печени для трансплантации. Донорам компенсируется потеря заработка во время восстановления здоровья после донорской операции в течение 12 недель или предоставляется право на сокращение рабочего времени на этот период ${ }^{12}$. Другие меры поощрения доноров запрещены, закон позволяет участвовать в прижизненном донорстве только в альтруистической форме. Статья 56 Закона «Human Tissue Act» от 2008 г. устанавливает штрафр 50000 долларов за продажу органов и тканей человека или лишение свободы на срок до 1 года ${ }^{13}$.

В США прижизненное донорство также осуществляется только при добровольном пожертвовании доноров. Раздел 42 Кодекса США, регулирующего правовые вопросы здравоохранения и социального обеспечения, содержит § $274 \mathrm{e}$ «Запрет покупки органов», при нарушении которого на виновное лицо налагается штрафр в размере не более 50000 долларов США или лишение свободы на срок не более чем 5 лет либо оба наказа-

${ }^{11}$ Cм.: Ghods A. J., Savaj Sh. Iranian Model of Paid and Regulated Living-Unrelated Kidney Donation // American Society of Nephrology. 2006. Vol. 1, № 6. P. 11361145. URL: https://doi.org/10.2215/CJN.00700206

${ }^{12}$ См.: Compensation for Live Organ Donors Act 2016 № 96. URL: https://www. legislation.govt.nz/act/public/2016/0096/25.0/DLM4297829.html (дата обращения: 10.05.2021).

${ }^{13}$ Cm.: Human Tissue Act 2008 (reprint as at 1 December 2020). URL: https:// www.legislation.govt.nz/act/public/2008/0028/latest/whole.html (дата обращения: 10.05.2021). 


\section{Вестник ВГУ. Серия: Право}

ния $^{14}$. В 2016 г. в стране был принят закон, направленный на защиту от дискриминации живых доноров органов, согласно которому страховым компаниям запрещено отказывать в страховых выплатах лицам, принимавшим участие в программах прижизненного донорства, а также ограничивать каким-либо образом их права. Неправомерным будет являться отказ в страховых выплатах при установлении живым донорам инвалидности, как и отказ в долгосрочном страховании здоровья, долгосрочного медицинского ухода в случае болезни ${ }^{15}$. Во многих штатах введены дополнительные социальные меры поддержки доноров: дополнительный оплачиваемый отпуск, налоговый кредит, социальный налоговый вычет. Наиболее высокой мерой социальной поддержки является налоговый кредит штата Юта, который покрывает до 10000 долларов неосвоенных расходов (поездки, проживание, потерянная заработная плата и медицинские расходы), связанных с донорством органов или тканей ${ }^{16}$.

Данная политика, проводимая в США, обеспечила значительное сокращение листа ожидания органов, но их дефицит всё же наблюдается, несмотря на то что в соответствии с законодательством живыми донорами органов могут быть не только члены семьи или друзья, но и иностранные граждане, как проживающие в США, так и проживающие в других странах. Исследование реестра Центра распределения международных доноров за период с 1 января 2000 г. по 31 декабря 2016 г. показало, что только 2 \% приходится на долю международных доноров почек, большинство которых составляют испанцы (40 \%) и жители Азии $(21 \%)^{17}$.

Следовательно, необходимо наиболее эффрективно развивать национальное донорство органов. Развитие международного донорства весьма затруднительно, так как в странах действуют разные законы, регулирующие донорство органов, а также в связи с тем, что высокие затраты до-

${ }^{14}$ Cм.: 42 U.S. Code Title 42 - The public health and welfare. URL: https://www. law.cornell.edu/uscode/text/42/274е (дата обращения: 10.05.2021).

15 CM.: Living Donor Protection Act of 2016. URL: https://www.congress.gov/ bill/114th-congress/house-bill/4616/text (дата обращения: 10.05.2021).

${ }^{16}$ Cм.: Donor Leave Laws and Tax Deductions/Credits for Living Donors. URL: https://web.archive.org/web/20161011122058/https://www.kidney.org/sites/default/ files/LDTaxDed_Leave.pdf (дата обращения: 10.05.2021).

${ }^{17}$ См.: Ammary F. Al., Thomas A. G., Massie A. B. and other. The landscape of international living kidney donation in the United States // Am J Transplant. 2019. Vol. 19, № 7. P. 2009-2019.

${ }^{18}$ Cm.: Levy $M$. State incentives to promote organ donation: honoring the principles of reciprocity and solidarity inherent in the gift relationship // J Law Biosci. 2018. Vol. 5, № 2. P. 398-435. 
предоставляются социальные льготы членам семей умерших доноров органов в виде 50\%-ной скидки на лечение в государственных клиниках на пятилетний срок, с момента изъятия органов у умершего родственника ${ }^{19}$. В Израиле с 2008 г. законом предусмотрены льготы для потенциальных доноров, выразивших согласие на изъятие органов после смерти, - приоритет в списке трансплантатов, если им потребуется донорство органов, в том числе для членов их семьи. Следует заметить, в стране узаконено и прижизненное неродственное донорство с возмещением медицинских расходов и потерянной работы в размере до 18000 шекелей (5500 долларов США), однако они возмещаются только в случаях их необходимости, а не по факту изъятия органа ${ }^{20}$.

Данные меры действительно могут мотивировать человека при жизни выразить согласие на донорство органов после смерти. Положительной стороной является заблаговременное прижизненное офрормление согласия потенциальных доноров. В России родственники часто запрещают изъятие органов для трансплантации у умерших пациентов из-за моральных и религиозных взглядов, несмотря на то что законом установлена презумпция согласия на донорство ${ }^{21}$. Рассмотренные меры социальной поддержки посмертного донорства рассчитаны, прежде всего, на малоимущее население, но они не приводят к социальному неравенству людей в обществе, поскольку не посягают на здоровье малоимущих при их жизни. В связи с этим считаем необходимым развивать социальные меры поддержки потенциальных доноров, выразивших согласие на изъятие органов после их смерти.

Российское законодательство не предусматривает мер социальной поддержки как прижизненного, так и посмертного донорства органов и запрещает неродственное прижизненное донорство. Исследование фринансовой мотивации российских граждан в прижизненном донорстве органов показывает заинтересованность 30 \% населения, участвующих в данном опросе 22 , поэтому меры социальной поддержки потенциальных доноров могли бы снизить острый дефицит органов в стране.

Таким образом, международное правовое регулирование прижизненного возмездного донорства органов является эфрфективным стимулом развития национальных законодательств по данному вопросу. Одни

${ }^{19}$ См.: Наббикова Г., Слирнова О. Правовые проблемы донорства // Вестник научных достижений. 2018. № 1. С. 30-32.

${ }^{20}$ Cм.: Berzon C. Israel's 2008 Organ Transplant Law: continued ethical challenges to the priority points model // Isr J Health Policy Res. 2018. Vol. 7, № 11.

${ }^{21}$ См.: Басова А. В. Конституционные права человека на трансплантацию и донорство органов : проблемы реализации // Система конституционного права современной России : ценности, принципы, институты и нормы : материалы XI Междунар. конституционного форума, посвященного 110-летию Саратовского гос. ун-та имени Н. Г. Чернышевского. Саратов, 2020. С. 25-28.

${ }^{22}$ См.: Роланов С. В. Применение фракторов фринансовой мотивации для доноров органов : зарубежный опыт и отношение россиян // Саратовский науч.-мед. журнал. 2018. Т. 14, № 3. С. 448-450. 
страны в национальные законодательства стали включать положения о социальной заинтересованности живых доноров органов, другие, отличающиеся консервативным подходом в регулировании вопросов донорства, включают меры социальной поддержки потенциальных доноров и членов их семей за будущий акт посмертного донорства.

Однако все страны, за исключением Ирана, так и не признали прижизненного возмездного донорства органов (узаконенную фринансовую компенсацию) в связи с высокими рисками дискриминации социально уязвимых групп населения, нарушения равного и справедливого распределения органов среди нуждающихся в трансплантации. Жизнь людей нельзя спасать за счет здоровья и инвалидизации других. Право на прижизненное донорство не должно рассматриваться через материальные и социальные интересы человека, даже если они компенсируются государством. Методы спасения человеческих жизней должны быть определены в четко выстроенной системе выявления потенциальных посмертных доноров; в проведении социально-ориентированной политики биоэтического воспитания населения по вопросам посмертного донорства.

\section{Библиографический список}

Басова A. В. Конституционные права человека на трансплантацию и донорство органов : проблемы реализации // Система конституционного права современной России : ценности, принципы, институты и нормы : материалы XI Междунар. конституционного форума, посвященного 110-летию Саратовского гос. ун-та имени Н. Г. Чернышевского. Саратов, 2020. C. 25-28.

Биопротезирование. История и современность / А. М. Морозов [и др.] // Современные проблемы науки и образования. 2019. № 4. С. 139.

Михель Д. В., Резник О. Н. Перспективы развития прижизненного неродственного донорства в России : междисциплинарный анализ // Апории современной трансплантологии / под ред. О. Н. Резника. М., 2020. URL: https://ssrn.com/abstract=3488672

Наббикова Г., Слирнова О. Правовые проблемы донорства // Вестник научных достижений. 2018. № 1. С. 30-32.

Роланов С. В. Применение фракторов финансовой мотивации для доноров органов : зарубежный опыт и отношение россиян // Саратовский науч.-мед. журнал. 2018. Т. 14, № 3. С. 448-450.

Ammary F. Al., Thomas A. G., Massie A. B. and other. The landscape of international living kidney donation in the United States // Am J Transplant. 2019. Vol. 19, № 7. P. 2009-2019.

Berzon C. Israel's 2008 Organ Transplant Law: continued ethical challenges to the priority points model // Isr J Health Policy Res. 2018. Vol. 7, № 11.

Ghods A. J., Savaj Sh. Iranian Model of Paid and Regulated LivingUnrelated Kidney Donation // American Society of Nephrology. 2006. Vol. 1, № 6. P. 1136-1145. 
Levy $M$. State incentives to promote organ donation: honoring the principles of reciprocity and solidarity inherent in the gift relationship // J Law Biosci. 2018. Vol. 5, № 2. P. 398-435.

Sachdeva S. Organ donation in India: Scarcity in abundance // Indian J Public Health. 2017. Vol. 61, № 4. P. 299-301.

\section{References}

Basova A. V. Constitutional human rights for organ transplantation and donation: problems of implementation // The system of constitutional law of modern Russia: values, principles, institutions and Norms. Materials of the XI International Constitutional Forum dedicated to the 110th anniversary of the Saratov State University named after N. G. Chernyshevsky. Saratov, 2020. P. 25-28 (In Russ).

Bioprosthetics. History and modernity / A. M. Morozov [et al.] // Modern problems of science and education. 2019. № 4. P. 139.

Mikhel V. D., Reznik O. N. Prospects for the Development of Living Unrelated Donation in Russia: An Interdisciplinary Analysis // Aporia of Modern Transplantology / ed. Oleg Reznik). M., 2020. URL: https://ssrn.com/abstract=3488672 (In Russ).

Nafikova G., Smirnova O. Legal problems of donation // Bulletin of scientific Achievements, 2018. № 1. P. 30-32 (In Russ).

Romanov $S$. $V$. The use of factors of financial motivation for organ donors: foreign experience and the attitude of Russians // Saratov Scientific and Medical Journal, 2018. Vol. 14, № 3. P. 448-450 (In Russ).

Ammary F. Al., Thomas A. G., Massie A. B. and other. The landscape of international living kidney donation in the United States // Am J Transplant. 2019. Vol. 19, № 7. P. 2009-2019.

Berzon C. Israel's 2008 Organ Transplant Law: continued ethical challenges to the priority points model // Isr J Health Policy Res. 2018. Vol. 7, № 11.

Ghods A. J., Savaj Sh. Iranian Model of Paid and Regulated Living-Unrelated Kidney Donation // American Society of Nephrology. 2006. Vol. 1, № 6. P. 1136-1145.

Levy $M$. State incentives to promote organ donation: honoring the principles of reciprocity and solidarity inherent in the gift relationship // J Law Biosci. 2018. Vol. 5, №. 2. P. 398-435.

Sachdeva S. Organ donation in India: Scarcity in abundance // Indian J Public Health. 2017. Vol. 61, № 4. P. 299-301.

\section{Для иитирования:}

Басова А. В. Международное правовое регулирование возмездного прижизненного донорства органов для трансплантации : проблемы применения // Вестник Воронежского государственного университета. Серия: Право. 2021. № 3 (46). C. 273-282. DOI: https://doi.org/10.17308/vsu.proc.law.2021.3/3557

\section{Recommended citation:}

Basova A. V. International legal regulation of paid lifetime organ donation for transplantation : problems of application // Proceedings of Voronezh State University. Series: Law. 2021. № 3 (46). P. 273-282. DOI: https://doi.org/10.17308/vsu.proc.law.2021.3/3557 
Вестник ВГУ. Серия: Право

Саратовский государственный медииинский университет илени В. И. Разумовского

Басова А. В., кандидат юридических наук, доцент кафбедры общественного здоровья и здравоохранения

E-mail:allsar@rambler.ru
Saratov State Medical University named after V. I. Razumovsky

Basova A. V., Candidate of Legal Sciences, Associate Professor of the Public Health and Health Care Department

E-mail: allsar@rambler.ru 